\title{
VYUŽITIE TEÓRIE KRITICKÝCH FAKTOROV ÚSPECHU PRI DOSAHOVANÍ KONKURENČNEJ VÝHODY
}

\author{
Monika Ďugelová ${ }^{1}$ - Mariana Strenitzerová ${ }^{2}$
}

\begin{abstract}
The strategic capability achieving with appropriate resources is an important factor for fighting the downturns. The organisations need to find the right resources and qualifications to gain competitive advantage. The theory of Critical Success Factor can help to join a strategy and the possibilities of organisation. The purpose of our paper is to show the importance of Critical Success Factor for organisation and possibilities of implementation the theory to the strategy analysis process.
\end{abstract}

Keywords: Critical Success Factor, Balanced Scorecard, Strategy analysis, VRIO theory.

\section{Úvod}

Po vypuknutí svetovej hospodárskej krízy si väčšina organizácií uvedomila, že už nie je dôležitá výška zisku ani doterajšie postavenie spoločnosti. V zmenených „vojnových“ podmienkach začalo zrazu vel'a z nich bojovat' o vlastnú existenciu a kládli si otázku, ako zlepšit' svoje postavenie na trhu a ako získat' zákazníkov na svoju stranu. Riešenie našla väčšina organizácií v hl'adaní konkurenčnej výhody. V hl’adaní takých schopností, zručností alebo zdrojov, ktoré jej zabezpečia jedinečnú a nenapodobitel’nú konkurenčnú výhodu, stále miesto na trhu a verných zákazníkov, ktorí sú základom každej úspešnej organizácie.

Ciel'om príspevku je okrem iného priblížit' teóriu kritických faktorov úspechu z pohl'adu jej využitia pri definovaní stratégie a možnost' využitia tejto teórie pri hl'adaní pôvodcu konkurenčnej výhody organizácie na trhu. Zároveň chceme poukázat' na dôležitost' strategického riadenia a nutnost' vychádzat' pri každom hl'adaní konkurenčnej výhody resp. nevýhody $\mathrm{z}$ dlhodobého pohl’adu na organizáciu a jej smerovanie.

\section{Teoretické východiská}

Kritické faktory úspechu (Critical Success Factor, CSF) definuje John Rockhart ako niekol'ko klúčových oblastí aktivít organizácie, v ktorých je nutné dosiahnut' požadované výsledky, aby boli naplnené ciele organizácie a jej vízia. Johnson a Scholes definujú kritické faktory úspechu ako tie aspekty stratégie, v ktorých musí organizácia vynikat', aby dokázala získat' konkurenčnú výhodu a ktoré sú podložené kl'účovými kvalifikáciami v špecifických aktivitách alebo v riadení vzt'ahov medzi aktivitami. Pôvod týchto faktorov môžeme nájst' vo viacerých oblastiach [1]:

\footnotetext{
${ }^{1}$ Ing. Monika Ďugelová, Žilinská univerzita v Žiline, Fakulta prevádzky a ekonomiky dopravy a spojov, Katedra spojov, Univerzitná 1, 01026 Žilina, tel. 041 5133145, e-mail: monika.dugelova@ fpedas.uniza.sk ${ }^{2}$ doc. Ing. Mariana Strenitzerová, PhD., Žilinská Univerzita v Žiline, Fakulta prevádzky a ekonomiky dopravy a spojov, Katedra spojov, Univerzitná 1, 01026 Žilina, Slovenská republika tel. 00421-041-5133 131, fax 00421-041-5655 615, e-mail: Mariana.Strenitzerova@fpedas.uniza.sk
} 
- odvetvie, v ktorom organizácia podniká,

- konkurenčné postavenie organizácie,

- Širšie okolie, v ktorom organizácia pôsobí,

- úroveň manažmentu.

Kritické faktory úspechu sú pre každý subjekt podnikania obmedzené počtom oblastí, v ktorých výsledok, ak je dostatočne vysoký, zabezpečí organizácii úspech v konkurenčnom prostredí. Sú to teda dôležité oblasti, v ktorých musí všetko fungovat' správne, aby organizácia splnila svoje predsavzatia a zámery.

Vybranou organizáciou, na ktorej chceme demonštrovat' využitie analýzy CSF pre dosiahnutie konkurenčnej výhody a pre definovanie a implementáciu stratégie, je malý portál so 6 zamestnancami, ktorý pôsobí na slovenskom trhu už 4 roky, z toho rok vydáva aj vlastný online časopis a vystupuje ako online médium. Základ príjmov portálu tvorí reklama na stránke alebo v online časopise a poplatky od klientov za zverejnenie ich vizitiek v Katalógu firiem. Portál taktiež poskytuje pre firmy možnost' vytvorenia vlastného blogu a zorganizovanie sút'aže s prezentáciou firmy, obe za poplatok.

Vedenie portálu tvorí manželský pár, ktorý sa rozhodol nanovo zadefinovat' a zaviazat' sa plnit' víziu, stratégiu a ciele organizácie a vytvorit' podmienky pre získanie konkurenčnej výhody a zlepšenie svojho postavenia na slovenskom ako aj českom trhu.

\section{Ciele a použitá metodika}

Ciel'om príspevku, ako už bolo naznačené v predchádzajúcej kapitole, je dokázat' využitie analýzy CSF pre dosiahnutie konkurenčnej výhody podniku. Zároveň chceme ukázat', že aj malé podniky, ktoré pôsobia online a poskytujú služby a ktorých je v súčasnosti v elektronickom podnikaní najviac (podl'a portálu pricemania.sk až 88,2\% elektronických obchodov na Slovensku tvoria malé podniku s počtom zamestnancov 1-5), majú potenciál pre implementáciu strategického riadenia a pre dlhodobé plánovanie využitia zdrojov. [2]

Použitými metódami boli najmä metódy analýzy a syntézy, čiže rozkladu celku na menšie časti a ich následné spájanie za účelom získania nového pohladu a metódy indukcie a dedukcie, ktoré budú slúžit' na vyhodnotenie skúmaných javov a vyvodenie záverov na základe ich pripodobnenia $\mathrm{k}$ tvrdeniam $\mathrm{v}$ iných vedeckých prácach.

\section{Analýza súčasného stavu riešenej problematiky}

Analýza CSF vyzdvihuje dôležitost' vzt'ahov medzi zdrojmi, kvalifikáciami a vol'bou stratégie. Pri definovaní strategickej spôsobilosti organizácie, ako aj pri strategickej analýze a implementácii stratégie, nie sú dôležité iba zdroje, ale aj ich kvalifikácie, čiže také schopnosti organizácie využit' zdroje, ktoré jej umožnia vyniknút' nad konkurenciou. Analýza kritických faktorov úspechu tak môže byt' poslednou čast'ou strategickej analýzy a základom strategického výberu a implementácie stratégie.

\subsection{Využitie CSF pri analýze strategickej spôsobilosti}

V časti strategickej analýzy odporúčajú autori Johnson a Scholes využitie CSF pri analýze strategickej spôsobilosti organizácie, pri identifikácii klúčových otázok abstrahovaných z auditu zdrojov a analýzy kvalifikácií zdrojov (pozri obrázok č. 1). Vzhl'adom k prirodzenému prepojeniu strategickej analýzy a výberu využívajú mnohé organizácie CSF ako kritický nástroj na posúdenie strategických informácií získaných z analýzy zdrojov. [1] 


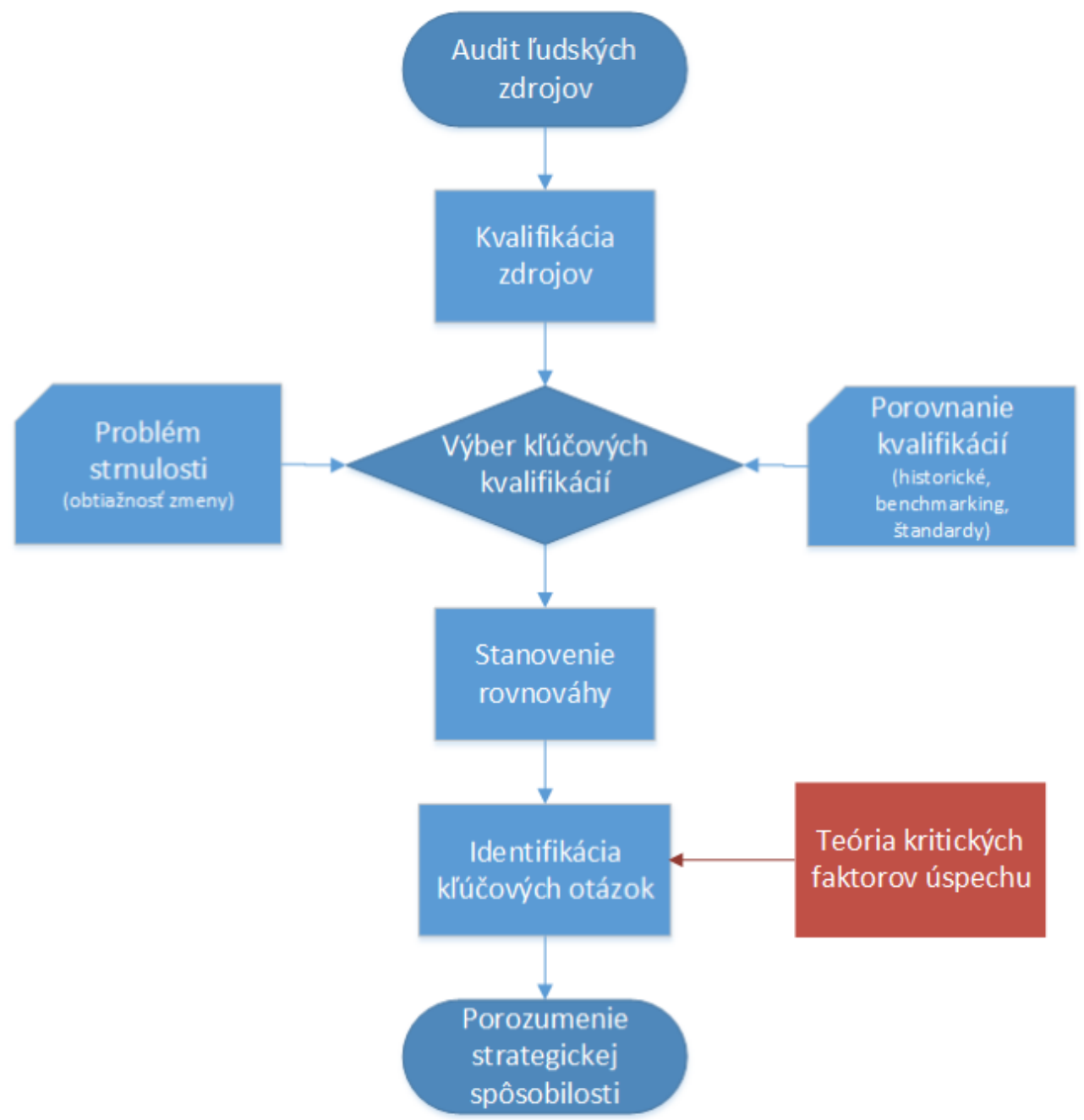

Obrázok 1. Umiestnenie teórie kritických faktorov úspechu do postupnosti analýzy strategickej spôsobilosti organizácie (Zdroj: Autor podl’a Johnson, G., Scholes, K.: Cesty k úspešnému podniku. Praha: Computer Press, 2000. 803 s. ISBN 80-7226-220-3)

\subsection{Využitie CSF pri implementácii stratégie}

V časti implementácie stratégie zasa Johnson a Scholes navrhujú teóriu CSF ako najvhodnejšiu metódu pre určenie rozmiestnenia a kontroly zdrojov, presnejšie pri príprave plánu zdrojov. Význam plánovania zdrojov spočíva $v$ identifikácii kritických faktorov pre úspech určitej stratégie a následné stanovenie priorít, rozpisov a rozpočtov. Je potrebné zaistit', aby zdroje a kvalifikácie boli rozmiestnené tak, aby mohli podporovat' určité stratégie žiadané danou organizáciou. Plánovanie rozmiestnenia zdrojov je taktiež súčast'ou hodnotenia stratégie, čiže uskutočnitel'nosti implementácie stratégie a jej uvedenia do praxe. [1]

Analýza kritických faktorov úspechu sa väčšinou skladá z nasledujúcich častí [1]:

- Identifikácia kritických faktorov úspechu pre špecifickú stratégiu.

- Identifikácia podporných kvalifikácií potrebných pre získanie konkurenčnej výhody prostredníctvom daných CSF.

- Podrobné preskúmanie zoznamu.

- Identifikácia výkonnostných štandardov, ktoré je potrebné dosiahnut' pre získanie konkurenčnej výhody.

- Odhad rozsahu, v ktorom môžu konkurenti napodobnit' jednotlivé kvalifikácie.

- Posúdit' dopad potenciálnych konkurenčných útokov a obranu voči nim. 
Každá čast' si vyžaduje osobitný prístup, ako možno vidiet' na obrázku č. 2 a je taktiež potrebné stanovit' zodpovednost' sa každú aktivitu v rámci CSF. Je potrebné zaistit' celistvost' vykonávania analýzy a zodpovedné oddelenia a osoby, ktoré zabezpečia hladký priebeh bez výraznejších komplikácií.

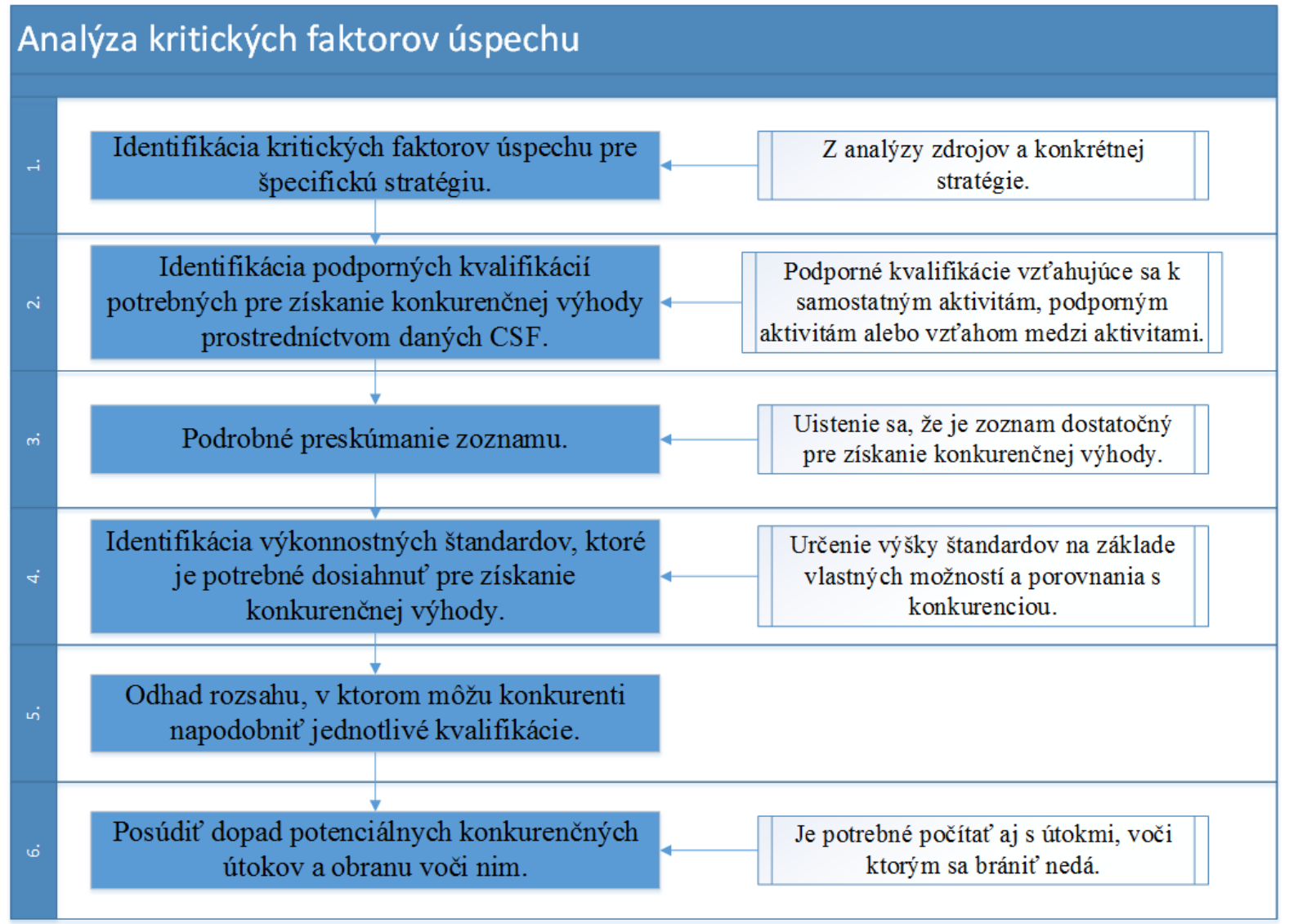

Obrázok č. 2 Postupnost' krokov analýzy kritických faktorov úspechu (Zdroj: Autor podl’a Johnson, G., Scholes, K.: Cesty $k$ úspešnému podniku. Praha: Computer Press, 2000. 803 s. ISBN 80-7226-220-3)

Pri kontrole zdrojov a ich rozmiestnení je taktiež možné vychádzat' z analýzy kritických faktorov, ak vykonávame kontrolu prostredníctvom stanovenia výkonnostných ciel'ov. Kontrola prostredníctvom stanovenia výkonnostných ciel'ov sa neobmedzuje iba na zásadné zmeny alebo krízy. Stále viac sa používa v organizáciách, ktoré chcú dosiahnut’ zisk prostredníctvom postúpenia decentralizácie.

Prvým krokom po stanovení kritických faktorov úspechu je prechod k systému merania výstupu prostredníctvom série dohodnutých indikátorov výkonu (PI), ktoré majú vzt’ah k štandardom najlepšieho výkonu. Vel'a organizácií považuje proces vývoja užitočného súboru indikátorov výkonu za príliš zložitý. Kým niektoré indikátory sú vo svojej podstate kvantitatívne, kvalitatívne sa stanovujú problematicky a na ich konci dominuje väčšinou finančná analýza. Ako pokus o vyriešenie tejto nesúrodej situácie boli navrhnuté vyrovnané výsledné účty alebo Balanced Scorecard. Balanced Scorecard kombinuje ukazovatele kvalitatívne a kvantitatívne, berie na vedomie očakávania rôznych investorov a je spojnicou medzi stanovením výkonu a výberom stratégie. [1]

Vyrovnaný výsledný účet môže byt' jednoduchý (vhodný pre malú organizáciu) alebo zložitejší (pre stredné a vel'ké organizácie). V oboch prípadoch dochádza k definovaniu kritických faktorov úspechu pre jednotlivé perspektívy (finančná, zákaznícka, vnútorných procesov a učenia sa a rastu), ich meradiel a centier zodpovednosti vychádzajúc zo stanovenej vízie podniku, stratégie a ciel'ov. 
Balanced scorecard, ako bolo spomenuté vyššie, nazerá na organizáciu a jej zdroje zo štyroch perspektív [3, 4]:

- perspektíva učenia sa a rastu - táto perspektíva zahŕňa vzdelávanie a školenie zamestnancov, ako aj postoje organizácie a implementovanej kultúry k sebazdokonal'ovaniu (zamestnancov, ale aj celej organizácie),

- perspektíva vnútorných procesov - sa dotýka, ako vyplýva z názvu, interných podnikových procesov; tento pohl'ad umožňuje manažérov ohodnotit' fungovanie organizácie a zistit' súlad medzi ponukou a dopytom (produktami a službami a zákazníckymi požiadavkami),

- zákaznícka perspektíva - perspektíva spokojnosti zákazníkov a schopnosti organizácie a jej zamestnancov uspokojit' neustále rastúce požiadavky trhu; nedostatočné zameranie sa na zákazníka môže spôsobit' v dlhodobom nazeraní výrazný pokles v ekonomických výsledkoch organizácie,

- finančná perspektíva - podl'a Kaplana a Northona nie je vhodné ignorovat' ani jedny z najklasickejších ukazovatel'ov; aktuálne a presné finančné údaje budú vždy prioritou a v súčasnom období je vel'mi dôležitá ich centralizácia a automatizácia prostredníctvom podnikových informačných systémov.

Využitie CSF pri Balanced Scorecard ako základnej časti implementácie podnikovej stratégie navrhli vo svojej práci aj Strenitzerova a Jandzikova (2010). Kritické faktory sa dotýkali l'udských zdrojov vel'kého siet’ového podniku a tvorili základ pre vyhodnocovanie plnenia stratégie riadenia l'udských zdrojov (pozri tabul'ku č. 1).

Tabul'ka č. 1 Balanced Scorecard riadenia l'udských zdrojov pre siet'ový podnik

\begin{tabular}{|c|c|c|}
\hline \multicolumn{2}{|c|}{ Ciele RL'Z } & Kritický faktor úspechu \\
\hline \multirow{13}{*}{ 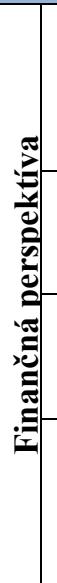 } & \multirow{4}{*}{$\begin{array}{l}\text { Zvýšit' nákladovú účinnost' l'udských } \\
\text { zdrojov }\end{array}$} & Rozpočtové vs. skutočné náklady \\
\hline & & Zisk na zamestnanca \\
\hline & & Osobné náklady na zamestnanca \\
\hline & & Podiel osobných nákladov na celkových nákladoch \\
\hline & \multirow[t]{2}{*}{ Zvýšit' efektívnost' l'udských zdrojov } & $\begin{array}{l}\text { Návratnost' investícií do l'udského kapitálu (HC ROI - Human } \\
\text { Capital Return of Investment) }\end{array}$ \\
\hline & & Pridaná hodnota na zamestnanca \\
\hline & \multirow{3}{*}{ Zvyšovat' produktivitu práce } & Produktivita práce $\mathrm{z}$ výnosov \\
\hline & & Mzdová produktivita \\
\hline & & Osobné náklady/Výnosy \\
\hline & \multirow{4}{*}{$\begin{array}{c}\text { Zníženie rozdielu medzi priemernou } \\
\text { mesačnou mzdou v SP, a. S., } \\
\text { a priemernou mesačnou mzdou } \\
\text { v hospodárstve SR }\end{array}$} & Mzdové prostriedky \\
\hline & & Priemerná mzda \\
\hline & & Štruktúra priemernej mzdy \\
\hline & & Mzdová rentabilita \\
\hline \multirow{14}{*}{ 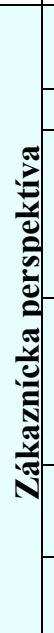 } & \multirow{2}{*}{ Vytvárat' pozitívne pracovné prostredie } & Index spokojnosti zamestnancov, lojalita zamestnancov \\
\hline & & Pracovná klíma a štýl riadenia v organizácii \\
\hline & Nadväzovat' strategické partnerstvá & Spätná väzba k zmluvám o poskytovaní služieb \\
\hline & \multirow{4}{*}{$\begin{array}{c}\text { Zaist'ovat' pripravenost' l'udského } \\
\text { kapitálu, efektívne plánovanie } \\
\text { l'udských zdrojov }\end{array}$} & Pripravenost' l’udského kapitálu \\
\hline & & Čerpanie dovolenky \\
\hline & & Percentuálny podiel pracovnej neschopnosti a OČR \\
\hline & & Využitel'nost' fondu pracovného času \\
\hline & \multirow{4}{*}{ Optimalizácia zamestnanosti } & Stav zamestnancov (PPEPZ) \\
\hline & & Stav zamestnancov podl'a vybraných kategórií \\
\hline & & Stav zamestnancov - podl’a týždenného pracovného času \\
\hline & & Stav zamestnancov prijatých na dobu určitú / na dohodu \\
\hline & \multirow{2}{*}{$\begin{array}{c}\text { Zníženie miery nežiaducej fluktuácie } \\
\text { zamestnancov }\end{array}$} & Miera stability a fluktuácie \\
\hline & & Miera nežiaducej fluktuácie \\
\hline & $\begin{array}{c}\text { Zmena systému zamestnaneckých } \\
\text { výhod }\end{array}$ & Miera spokojnosti so mzdou a zamestnaneckými výhodami \\
\hline
\end{tabular}




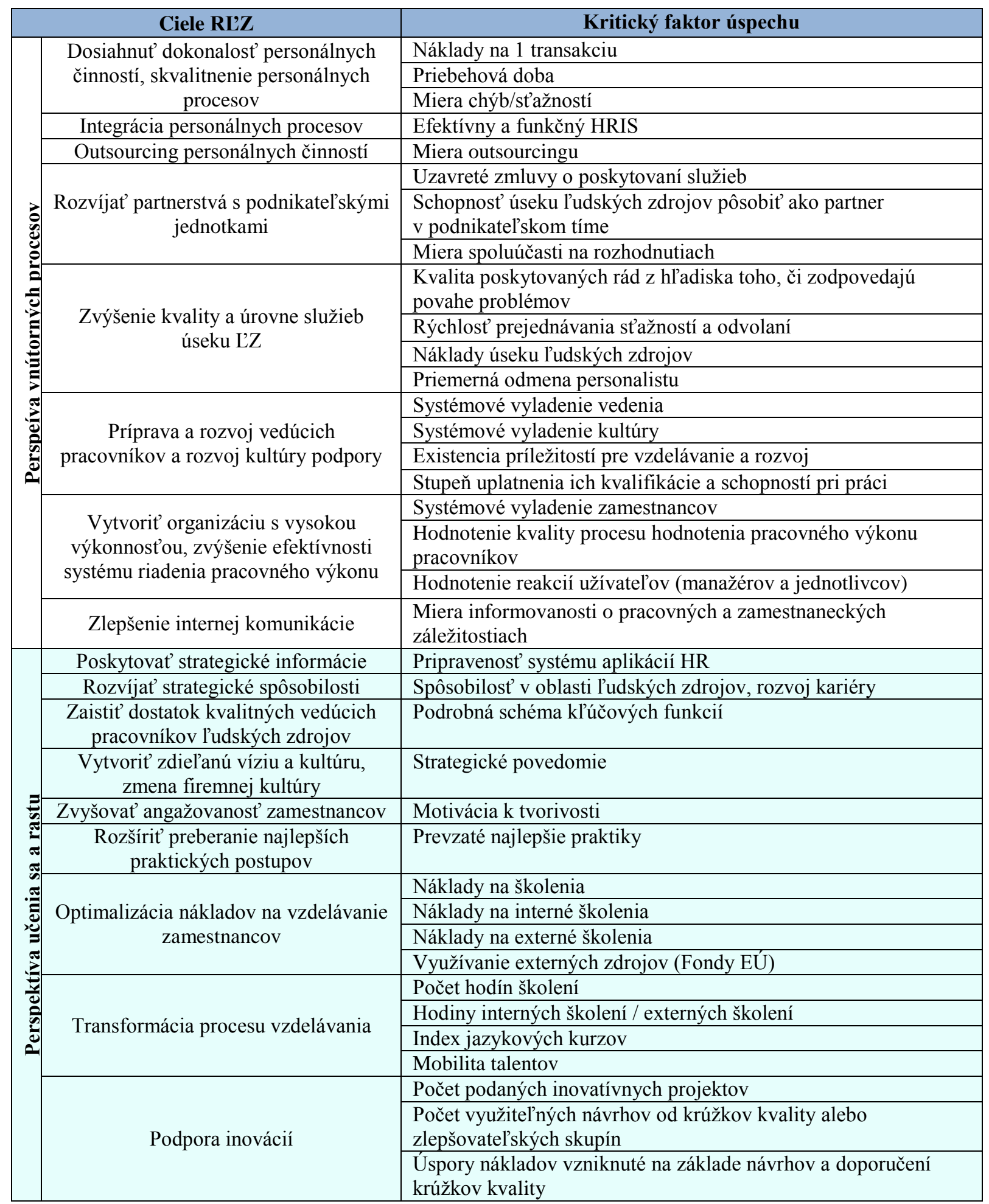

Zdroj: JANDZIKOVA, K., STRENITZEROVA, M.: Uplatnenie metodiky BSC pri vytváraní stratégie riadenia l'udských zdrojov v Slovenskej pošte, a. s. In: Pošta, telekomunikácie a elektronický obchod. 4/2010. s. . ISSN 1336-8281

Kritické faktory úspechu rozdelené podl’a týchto perspektív umožnia definovat' zdroje a kvalifikácie, ktoré ovplyvnia d'alšie smerovanie výkonnosti podniku. Balanced Scorecard ale neposkytuje iba rámec na meranie výkonu. Zároveň umožňuje naplánovat', čo by sa malo v organizácii sledovat' a merat', aby bolo možné realizovat' zvolenú stratégiu. 


\section{Diskusia a výsledky}

Ako sme rozoberali v kapitole č. 1, skúmanou organizáciou je malý portál so 6 zamestnancami, ktorý riadi manželský pár. Ten sa zároveň sám podiel'a na činnosti portálu a okrem riadiacich funkcií vykonáva aj d'alšie aktivity. Pred štyrmi rokmi pri vzniku portálu bolo celé strategické riadenie organizácie zadefinované prostredníctvom vízie: „Náš portál chce byt' rovnaký ako vy - zvedavý, inteligentný, hladný po informáciách, plný života, moderný, vtipný a hlavne zábavný! " Majitelia si taktiež definovali ciele do budúcnosti, ktoré boli počas pôsobenia portálu sčasti splnené, niektoré sa zavrhli a väčšina je už prekonaná, ked'že portál prešiel výraznými zmenami. Jednou z nich bol aj začiatok vydávania vlastného online časopisu, pre ktorý bola zakúpená nová doména. Ďalšou, vel'mi výraznou zmenou, bolo rozšírenie na český trh prostredníctvom vytvorenia českej verzie stránky a rovnako aj časopisu s podobnými, ale nie rovnakými článkami a príspevkami.

Na začiatku definovania stratégie portálu bolo potrebné vykonat' Analýzu strategickej spôsobilosti organizácie, ktorú sme vykonali podl’a schémy opísanej na obrázku č. 1 . Výsledkom bol výber klúčových kvalifikácií prostredníctvom VRIO metódy, ktorú sme ako vhodnú metódu pre túto činnost' navrhli pri riešení analýzy strategickej spôsobilosti l'udských zdrojov v predchádzajúcich článkoch. Jednotlivé faktory VRIO metódy vychádzali z auditu zdrojov organizácie vykonaného pred začiatkom definovania stratégie (pozri tabul'ku č. 1).

$\mathrm{Na}$ základe určenia strategických oblastí vhodných pre budúce smerovanie (starostlivost' o l'udské zdroje ako o najcennejší kapitál spoločnosti; starostlivost' o klientov a návštevníkov, udržanie si stálych a hl'adanie stále nových; múdre vedenie portálu zamedzujúce nekalým praktikám a neustále rozvíjanie povedomia značky na trhu) sme mohli spoločne s majitel'mi určit' víziu, poslanie a ciele organizácie na nasledujúce obdobie:

Vízia: „Náš portál chce byt' rovnaký ako vy - zvedavý, inteligentný, hladný po informáciách, plnýživota, moderný, vtipný a hlavne zábavný. Chce byt' lídrom na trhu a nechce pri tom robit'žiadne kompromisy. "

Poslanie: „Poslaním portálu je vzorne sa starat' o svojich zamestnancov, pretože tvoria najdôležitejšie aktívum organizácie, vzorne sa starat' aj o svojich klientov, pretože vd'aka nim portál prosperuje a prinášat návštevníkom vždy nové a zaujímavé informácie a oslovit široké spektrum návštevníkov. “

Ciele:

- V priebehu piatich rokov chceme na českom trhu dosiahnut' rovnaký podiel ako máme v súčasnosti na slovenskom trhu.

- Chceme rozširit' počet zamestnancov na 10 l'udi a zlepšit’ systém riadenia l'udských zdrojov.

- Chceme, aby sa minimálne z 80\% klientov stali stáli klienti (využívajú služby portálu viac ako 1 rok).

- Chceme rozšírit’ svoje portfólio služieb.

Z VRIO analýzy, definovanej vízie, poslania a ciel'ov a benchmarkingu z konkurenciou bola vykonaná analýza kritických faktorov úspechu. Kritickými faktormi úspechu, v ktorých musí organizácia vynikat', aby dokázala získat' konkurenčnú výhodu, sú po schválení majitel’ov tieto činnosti a aktivity organizácie:

- Detailný výber zamestnancov a starostlivost' o nich.

- Znalost' trhu a získanie verných a stále sa vracajúcich klientov aj návštevníkov portálu.

- Zvýšenie podielu portálu na českom trhu.

- Zdokonal'ovanie a neustále vyvíjanie nových služieb a produktov. 


\begin{tabular}{|c|c|c|c|c|}
\hline $\begin{array}{l}\text { Hrubá identifikácia } \\
\text { kritických faktorov }\end{array}$ & $\rightarrow$ & $\begin{array}{l}\text { Identifikácia } \\
\text { podporných kvalifiácií }\end{array}$ & & Detailná identifikácia kritických faktorov \\
\hline $\begin{array}{c}\text { Detailný výber } \\
\text { zamestnancov a } \\
\text { starostlivost' o nich }\end{array}$ & $\rightarrow$ & $\begin{array}{c}\text { Diferencovaný } \\
\text { systém hodnotenia } \\
\text { a motivácie }\end{array}$ & $\rightarrow$ & $\begin{array}{l}\text { Pocet zamestnancov spokojných so svojim } \\
\text { ohodnotením. } \\
\text { Počet prijatých žiadostí o vol'né miesto. } \\
\text { Počet uchádzačov pozvaných na pohovor. } \\
\text { Suma vynaložených peňažných prostriedkov na } \\
\text { ohodnotenie jedného zamestnanca. } \\
\text { Suma odmien za rok pre všetkých zamestnancov }\end{array}$ \\
\hline $\begin{array}{l}\text { Znalost' trhu a } \\
\text { získanie verných a } \\
\text { stále sa vracajúcich } \\
\text { klientov a } \\
\text { návštevníkov } \\
\text { portálu }\end{array}$ & $\rightarrow$ & $\begin{array}{l}\text { Zaujímavý a } \\
\text { prepracovaný } \\
\text { obsah, pravidelná } \\
\text { analýza trhu }\end{array}$ & & $\begin{array}{l}\text { Počet vykonaných analýz trhu/ mesiac. } \\
\text { Počet splnených mesačných cielov. } \\
\text { Počet nesplnených mesačných ciel'ov. } \\
\text { Suma vynaložená na získanie nových zákazníkov/ } \\
\text { rok. } \\
\text { Suma vynaložená na získanie verných zákazníkov/ } \\
\text { rok. }\end{array}$ \\
\hline $\begin{array}{l}\text { Zvýšenie podielu } \\
\text { portálu na českom } \\
\text { trhu }\end{array}$ & $\rightarrow$ & $\begin{array}{c}\text { Zlepšenie } \\
\text { marketingovej } \\
\text { komunikácie, } \\
\text { investícia do } \\
\text { českého portálu }\end{array}$ & & $\begin{array}{l}\text { Počet nových zákazníkov na českom portáli. } \\
\text { Suma vynaložená na prezentáciu portálu v Českej } \\
\text { republike. } \\
\text { Podiel portálu voči konkurencii na danom trhu. } \\
\text { Rast/ pokles návštevnosti portálu. } \\
\text { Náklady na prevádzkovanie českého portálu. }\end{array}$ \\
\hline $\begin{array}{l}\text { Zdokonal'ovanie a } \\
\text { neustále vyvíjanie } \\
\text { nových služieb a } \\
\text { produktov }\end{array}$ & $\mapsto$ & $\begin{array}{c}\text { Zväčšenie portfólia } \\
\text { služieb, inovatívne } \\
\text { produkty }\end{array}$ & & $\begin{array}{l}\text { Počet nových produktov/ mesiac. } \\
\text { Počet zmenených služieb/ mesiac. } \\
\text { Náklady na inovácie/ rok. } \\
\text { Zmena návštevnosti po implementácii inovácie. } \\
\text { Zmena záujmu zo strany klientov po implementácii } \\
\text { inovácie. }\end{array}$ \\
\hline
\end{tabular}

Obrázok č. 3 Analýza kritických faktorov úspechu pre vybraný podnik (Zdroj: Autor)

Ked’že organizácia je malá, pre každú perspektívu Balanced Scorecard bol definovaný jeden kritický faktor. Podl'a postupnosti analýzy kritických faktorov úspechu z kapitoly 3.2. sme kritické faktory úspechu posúdili v jednotlivých krokoch postupnosti a urobili rozklad na meratel'né kritické faktory úspechu (pozri obrázok č. 3).

Pre každý strategický ciel' sú tak určené meratel'né faktory, ktoré umožnia sledovat' priebežné plnenie ciel'a a celkovej stratégie organizácie. Kritické faktory môžu byt' taktiež použité pre kvalitnejšie ohodnocovanie práce zamestnancov, pre určenie rastu organizácie a jej celkového hospodárskeho výsledku. Dané faktory možno d'alej rozviest' pre určenie čiastkových stratégií jednotlivých funkčných oblastí organizácie.

Výsledné použitie Balanced Scorecard možno vidiet' v tabul'ke č. 2. Aby organizácia mohla splnit' strategické ciele, musí sa venovat' kritickým faktorom úspechu a sledovat' ich podl'a jednotlivých stanovených meradiel. Iba tak dokáže v budúcnosti splnit' stanovené ciele a dodržat' predstavu o budúcom smerovaní organizácie definovanú vo vízii a poslaní.

Kritické faktory boli vyberané so zretel'om na ich meratel'nost' a reálnu zistitel'nost' v organizácii. Nie je vylúčené, že v priebehu času sa budú menit', očakávaný je najmä rozvoj organizácie a s tým spojené využivanie kvalitnejších informačných systémov, ktoré umožnia detailnejšie skúmanie jednotlivých kvalifikácií. Organizácia má problém najmä s uchovávaním údajov o klientoch a s ich zdiel'aním medzi jednotlivými zamestnancami. Vývoj alebo nákup hotového informačného systému je z dôvodu finančných prostriedkov nemožný, do úvahy pripadá rozšírenie užívatel'ského prostredia na portáli, kde majú prístup všetci zamestnanci. Zatial' tento editovací nástroj neumožňuje komplexnejšie uchovávanie dát. 
Tabul'ka č. 2 Analýza Balanced Scorecard vybraného podniku

\begin{tabular}{|c|c|c|}
\hline & Strategický ciel' & Kritický faktor úspechu \\
\hline & & $\begin{array}{l}\text { Počet zamestnancov spokojných so svojím } \\
\text { ohodnotením. }\end{array}$ \\
\hline 氖 & $\mathrm{V}$ priebehu piatich rokov chceme na & Počet prijatých žiadostí o vol'né miesto. \\
\hline $\bar{\Xi}$ & českom trhu dosiahnut' rovnaký podiel ako & Počet uchádzačov pozvaných na pohovor. \\
\hline 动 & & $\begin{array}{l}\text { Suma vynaložených peňažných prostriedkov na } \\
\text { ohodnotenie jedného zamestnanca. }\end{array}$ \\
\hline & & Suma odmien za rok pre všetkých zamestnancov \\
\hline & & Počet vykonaných analýz trhu/ mesiac. \\
\hline 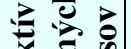 & Chceme rozšírit' počet zamestnancov na 10 & Počet splnených mesačných ciel’ov. \\
\hline $\bar{\Xi}$ & l'udí a zlepšit' systém riadenia l’udských & Počet nesplnených mesačných ciel’ov. \\
\hline 党异 & zdrojov. & Suma vynaložená na získanie nových zákazníkov/ rok. \\
\hline & & Suma vynaložená na získanie verných zákazníkov/ rok. \\
\hline & & Počet nových zákazníkov na českom portáli. \\
\hline 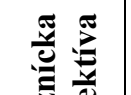 & Chceme, aby sa minimálne z $80 \%$ klientov & $\begin{array}{l}\text { Suma vynaložená na prezentáciu portálu v Českej } \\
\text { republike. }\end{array}$ \\
\hline 武 & viac ako 1 rok) & Podiel portálu voči konkurencii na danom trhu. \\
\hline & & Rast/ pokles návštevnosti portálu. \\
\hline & & Náklady na prevádzkovanie českého portálu. \\
\hline & & Počet nových produktov/ mesiac. \\
\hline$\underset{1}{\pi}$ & & Počet zmenených služieb/ mesiac. \\
\hline 荧 & Chceme rož̌́rit' syoie nortfólio slǔ̌ieh & Náklady na inovácie/ rok. \\
\hline 可 & & Zmena návštevnosti po implementácii inovácie. \\
\hline & & $\begin{array}{l}\text { Zmena záujmu zo strany klientov po implementácii } \\
\text { inovácie. }\end{array}$ \\
\hline
\end{tabular}

Zdroj: Autor

\section{Záver}

Analýza kritických faktorov úspechu je dôležitým nástrojom pri detailnom posudzovaní zvoleného strategického smerovania organizácie a umožňuje definovat' oblasti, ktoré by mala organizácia sledovat' pre dosiahnutie konkurenčnej výhody. Využitie CSF je nenáročné jeho princípy je možné použit' vo viacerých oblastiach strategickej analýzy.

V diskusii nášho príspevku sme použili CSF pri vykonaní metódy Balanced Scorecard a určili sme tak zdroje a kvalifikácie, ktoré by mala vybraná organizácia sledovat' pre splnenie definovaných strategických ciel'ov. Využitie CSF preto môžeme ohodnotit' ako vhodné a pri väčších organizáciách aj potrebné pre dosiahnutie konkurenčnej výhody. Umožňuje vytvorit' nadhl'ad na pôsobenie organizácie, spojit' interné aj externé faktory pôsobenia a zamedzit' tak jednostrannému pohl'adu na problematiku.

\section{Literatúra}

[1] Johnson, G., Scholes, K.: Cesty k úspešnému podniku. Praha: Computer Press, 2000. 803 s. ISBN 80-7226-220-3

[2] CHOVŇÁK, M.: Pricemania.sk: Vel'ký prieskum e-shopov. [online]. 2013. [cit. 2014-0426]. Dostupné na internete: <http://www.mojandroid.sk/2013/10/25/velky-prieskum-eshopov/>

[3] ŠTOFKOVÁ, J., ŠTOFKOVÁ, K.: Využitie metódy BSC v riadení podniku. IV. medzinárodná vedecká konferencia - zborník príspevkov : 17.-18. apríl 2008, Žilina. ISBN 978-80-8070-819-1. 
[4] BALANCED SCORECARD INSTITUTE: Balanced Scorecard Basics. [online]. 2013. [cit. 2014-04-26]. Dostupné na internete: $\langle\underline{\text { http://balancedscorecard.org/Resources/AbouttheBalancedScorecard/tabid/55/Default.as }}$ px>

[5] JANDZIKOVA, K., STRENITZEROVA, M.: Uplatnenie metodiky BSC pri vytváraní stratégie riadenia l’udských zdrojov v Slovenskej pošte, a. s. In: Pošta, telekomunikácie a elektronický obchod. 4/2010. s. . ISSN 1336-8281

\section{Grantová podpora}

Inštitucionálny výskum IV. Regulačné aspekty interoperability poštových systémov 